\title{
THE POSITIVE IMPACT OF BIOPROTECTIVE CULTURE ON CERTAIN BURGER PARAMETERS
}

\author{
Zora Uzunoska ${ }^{1}$, Zlatko Pejkovski ${ }^{2}$, Tanja Kalevska ${ }^{1}$, Daniela Beličovska ${ }^{3}$, \\ Katerina Beličovska ${ }^{2}$, Viktorija Stamatovska ${ }^{1}$ \\ l',St. Kliment Ohridski" University in Bitola, Faculty of Technology-and Technical Sciences - Nutrition, \\ Dimitar Vlahov bb, 1400 Veles, Republic of Macedonia \\ 2 "St. Cyril and Methodius" University in Skopje, Faculty of Agricultural Sciences and Food, \\ Blvd. Aleksandar Makedonski bb, 1000 Skopje, Republic of Macedonia \\ ${ }^{3}$ MIT University, Faculty of Environmental Resources Management, \\ Blvd. Treta Makedonska brigada bb, 1000 Skopje, Republic of Macedonia \\ zora_51@hotmail.com
}

\begin{abstract}
The aim of the study was to investigate the effect of bioprotective culture (Lactobacillus sakei) on certain parameters of burgers, under industrial condition. Four groups of burgers were produced: without additives (R), as referent ones; with additives and antioxidants (R/B/A); with bioculture B-2 SafePro (Lactobacillus sakei) added (R/L); and with B-2 SafePro, additives and antioxidants $(\mathrm{R} / \mathrm{L} / \mathrm{B} / \mathrm{A})$. The lowest $\mathrm{pH}$ was determined in $\mathrm{R} / \mathrm{L} / \mathrm{B} / \mathrm{A}$, and the highest in R/B/A, 3 days after production, although the difference was minimal (6.105 v. 6.125). However, 7 days after production, the difference between $\mathrm{R} / \mathrm{L}$ and the rest of the 3 groups was evident, the lowest $\mathrm{pH}$ was determined in $\mathrm{R} / \mathrm{L}$, and the highest in R products (5.792 v. 5.966). The grilling weight loss was the highest in $\mathrm{R} / \mathrm{L}$ compared to other groups, R, R/B/A. R/L/B/A (15.75\% v.14.225, 12.237, $12.75 \%)$. The best sensory characteristics were given to R/L and the worse to $R$ burgers, 7 days after production $(89.125 \mathrm{v}$. 48.125$)$. The results of 90 days storage $\left(\right.$ at $\left.-18^{\circ} \mathrm{C}\right)$, have showed the lowest values of Thibarbituric Acid Reductive Substances (TBARS) $(0.567 \mathrm{mg} / \mathrm{kg}$ ) in R/L/B/A. The highest total bacteria count (higher number of Lactobacillus sakei colonies notified) was present in R/L burgers. An addition of bioprotectective culture to burgers has a positive impact on their $\mathrm{pH}$, sensory characteristics and microbial profile inducing prolonged shelf life of burgers.
\end{abstract}

Key words: additives; biopreservatives; substitution; bioculture

\section{ПОЗИТИВЕН ИМПАКТ НА БИОПРОТЕКТИВНАТА КУЛТУРА НА ОДРЕДЕНИ ПАРАМЕТРИ НА ПЛЕСКАВИЦИТЕ}

Целта на трудот беше испитување на ефектот на биопротективната култура (Lactobacillus sakei) врз одредени параметри на плескавиците во индустриски услови. Беа произведени 4 групи плескавици: со адитиви (R), како референтни; со адитиви и антиоксиданси (R/B/A); со додадена биокултура B-2 SafePro (Lactobacillus sakei) (R/L); и со B-2 SafePro, адитиви и антиоксиданси (R/L/B/A). Најниска $\mathrm{pH}$ беше утврдена кај $\mathrm{R} / \mathrm{L} / \mathrm{B} / \mathrm{A}$, а највисока кај R/B/A, 3 дена од производството, иако таа разлика беше минимална $(6,105$ v. 6,125$)$. Меѓутоа, по 7 дена од производството, разликата меѓу R/L и другите 3 групи беше евидентна, најниска $\mathrm{pH}$ беше утврдена кај R/L, а највисока кај R-продуктите (5,792 v. 5,966). Загубата во тежина при печење беше највисока кај R/L во споредба со другите групи, R, R/B/A. R/L/B/A (15,75 \% v.14,225, 12,237, 12,75 \%). Најдобри сенсорни карактеристики имаa $\mathrm{R} / \mathrm{L}$, а најлоши $\mathrm{R}$-плескавиците 7 дена од производството $(89,125 \mathrm{v}$. $48,125)$. Резултатите од чувањето на производите 90 дена, на $-18^{\circ} \mathrm{C}$, покажуваат најниски вредности на редуктивни супстанции на тиобарбитуратна киселина (РСТБК) $(0,567 \mathrm{mg} / \mathrm{kg})$ кај продуктите R/L/B/A. Најголем број бактерии (за сметка на Lactobacillus sakei) беше присутен во R/L-плескавиците. Додавање биопротективна култура на плескавиците има позитивен импакт на нивната $\mathrm{pH}$, сензорните карактеристики и микробниот профил, индуцирајќи подолго траење на плескавиците.

Клучни зборови: адитиви; биопрезервативи; супституција; биокултура 


\section{INTRODUCTION}

Traditionally, the growth of undesirable microorganisms in meat and meat products is prevented by keeping them at low temperatures, cooking, fermentation, vacuum packaging and adding chemical additives (salt, organic acid, smoking, etc.).

An anaerobic, facultative anaerobic, and microaerophilic bacteria of the genera: Clostridium, Bacillus, Streptococcus, Lactobacillus and optionally the family Enterobacteriaceae can be found in depth of the meat. The surface of the meat always contains micro organisms, but their number depends on the hygiene during the work and the technology of the slaughter, processing, and cooling. A microflora of the fresh meat, comprises mesophilic microorganisms of the gender: Micrococcus, Brevibacter, Moraxella, Lactobacillus, Streptococcus, and more rarely Acinobacter, Leuconostoc, Mycobacterium and Pseudomonas. The surface of the cooled meat brings together representatives of the gender: Pseudomonas, Moraxella, Brochothris and some genera of the family Enterobacteriaceae. A smaller proportion of isolated representatives of gender: Flavobacterium, Alcaligenes, Vibrio, Aeromonas and Arthrobacter can be found, as well. Penicillium, Cladosporium, Thamidium, Mucor, Rhisopus and Aspergillus can be isolated from the cooled meat surface mold [4]. Minced meat spoils much faster than meat in pieces, since it has a larger surface exposed to the environment. During the aerobic storage, a development of aerobic bacteria (predominantly Pseudomonas) can occur, which causes changes in the smell, color and texture of the meat. Within the period of 3-4 weeks at a temperature of storage of $+7^{\circ} \mathrm{C}$, pathogenic bacteria, tolerant of low temperatures and bacteria that cause spoilage of the products, can increase their number to an unacceptable level. One of the most pathogenic bacteria present in a raw or vacuumed meat is Listeria monocytogenes. These bacteria are able to grow at low temperatures and therefore represent a serious problem for the consumer's health [35].

Traditional preservatives (high salt concentrations, nitrites, artificial stabilizers and intense heat treatment) against such a wide spectrum of potential microbial contamination of the meat and meat products were sufficient for providing safe and cost-effective supply of the market with meat products in the past. However, many scientific data suggest that a long-term consumption of food products containing additives of chemical origin may result in a range of health disorders in humans. Phosphate and polyphosphate mixtures may induce cytotoxic effects and gastriointestinal problems. Nitrites are potential toxic, carcinogenic and mutagenic additives [27]. Inspired by these scientific observation, the actual tendency towards healthier food for consumers and the interest of food operators for offering meat and meat products with a prolonged shelf life and better sensory characterristics, a new technologies of bioconservation have been introduced [12] such as using Lactic Acid Bacteria (LAB).

Lactic acid bacteria are comprised of at least ten genera according to taxonomic revisions representing Aerococcus, Carnobacterium, Enterococcus, Lactobacillus, Lactococcus, Leuconostoc, Pediococcus, Streptococcus, Tetragenococcus and Vasococcus [18]. They are widely used as starter cultures in a variety of food fermentations [14] protecting the food without any visible or adverse organoleptic changes. The selected strains of Grampositive facultative and hetero-fermentative anaerobic bacteria of Lactobacillus and Pediococcus gender are the most often LAB used [25]. LAB can be used as a purely protective culture in a fresh meat and vacuum products [16]. It is well known that many LAB show antagonistic activities against other bacteria, including spoilage organisms of the meat products $[1,13]$ and food borne pathogens. $\mathrm{LAB}$ can promote a revitalization of the positive microflora and prevent the development of undesirable microflora, so the need for application of physical or chemical preservation have been reduced [6]. There are several different mechanisms responsible for this inhibition. In most cases, the inhibition is caused by the production of organic acid, hydrogen peroxide and bacteriocins. Bacteriocins are small peptides that disrupt the integrity of bacterial cell membranes. As an alternative tool to control pathogenic bacteria, antimicrobial peptides or bacteriocins are recently being considered. $\mathrm{LAB}$ are one of the major resources for bacteriocin biosynthesis [23].

The main role of LAB is associated with the metabolism of carbohydrates which results in acidification of the meat. This process provides hygienic stability by $\mathrm{pH}$ reduction; it causes coagulation of proteins in the meat ( $\mathrm{pH} 5.4$ to 5.5); contributes to development of desired red color providing a proper reaction between nitrogen monoxide and myoglobin ( $\mathrm{pH} 5.4$ to 5.5). Lactobacilli used as starters in the meat, produce lactic acid as a main product of fermentation by using glucose and hexose-phosphate due to glycolysis process. Prote- 
olysis activity of LAB contributes to development of the taste by releasing of peptides and free amino acids. Several egzopeptidases are isolated and characterized from $L$. sakei, which highlights its role in peptide degradation during the meat fermentation process [24]. The application of LAB for extending the shelf life of meat products has a long tradition. Also, LAB improves the texture of meat itself [16]. Species of L.sakei and L. curvatus microorganisms are the most competitive types in the meat fermentation process. These species are psychotropic with optimal growth temperature of $25-30^{\circ} \mathrm{C}$.

Lactobacillus sakei is an important foodassociated LAB. Although initially characterized from rice wine and isolated from plant fermentations [34, 17] and fermented fish, its main habitat is meat [11]. It is widely used as a starter culture in the production of fermented meat products [12], and is regarded as a potential meat and fish biopreservative [32]. In 1991, a survey about the acidification profile of Lactobacillus sakei was performed. In liquid medium (MRS-IM) at a temperature of $10^{\circ} \mathrm{C}, 1 \%$ sugar, which is an important component in the meat production, had been added. An acidification process was observed in the medium where sucrose (a disaccharide consisting of fructose and glucose) was added, as well as in the medium with glucose added. However no acidification was noted in media with lactose or maltose added.

L. sakei resists harsh conditions which often prevail during preservation, such as high salt concentration, low water activity, low temperature and $\mathrm{pH}$ [3]. An important property of the bacterium is the production of lactic acid that acidifies the product and both inhibits growth of spoilage bacteria and food pathogens, and confers taste and texture to the fermented products. The species has also been observed as a transient inhabitant of the human gastrointestinal tract [7]. Sequence analysis of the $L$. sakei $23 \mathrm{~K}$ genome has provided valuable information, showing a specialized metabolic repertoire that reflects adaptation to meat products [6]. These efforts revolutionized our molecular view of Gram-positive bacteria, as up to 15 genomes from the low GC content lactic acid bacteria are available in the public domain. Our collective view of the lactic acid bacteria will be fundamentally changed as we rediscover the relationships and capabilities of these organisms through genomics.

B-2 SafePro, is a bioprotective culture (BC) comprised of Lactobacillus sakei (microaerophilic bacteria) in a frozen-dry form, applied into dry and semi dry meat products. Colonies of Lactobacillus sakei on NRC agar are white, rod-shaped, their edges touching, forming a central cavity. The diameter of the colony is 2 to $3 \mathrm{~cm}$. Theoretical and experimental findings are dating back to 1987, when it was first isolated from the fresh steak packaged in a modified atmosphere. By now, applying the B-2 SafePro results in the inhibition of bacteria: Listeria monocytogenes, Brochothrix thermosphacta, Leuconostoc sp. etc. that belong to the putrefying microflora, which occurs as a result of temperature changes mode during the products storage. Development of B-2 SafePro in the product induces a conversion of certain amount of the sugar to lactic acid. In order to prevent excessive acidity of the product, using nonferment carbohydrates such as lactose, maltose or malt dextrin are better choice compared to glucose and sucrose [36]. This bioprotective culture is capable of growth and development at a temperature of $2^{\circ} \mathrm{C}$, but the optimum temperature for growth in MRSagar is $35^{\circ} \mathrm{C}$. However, a temperature below $20^{\circ} \mathrm{C}$ and over $40^{\circ} \mathrm{C}$ results in reduction of acidification process. An addition of salt and a temperature of 20 to $40^{\circ} \mathrm{C}$ make the acidification slowdown. The maximum concentration of $6 \%$ salt at which growth and development of B2 SafePro is possible, but the level of inoculation should be higher than $10^{6} \mathrm{CFU} / \mathrm{ml}$. A salt concentration of $4 \%$, and $10^{4}$ $10^{5} \mathrm{CFU} / \mathrm{ml}$ level of inoculation stops the growth of bioprotective culture. Therefore a proper incubation temperature, determination of salt concentration and the level of inoculation are of vital importance for the normal growth and development of B-2SafePro. Thus the shortest time for growth and development of this culture is achieved when the temperature is optimal, salt concentration low and a level of inoculation high.

Lactobacillus sakei can retain its activity with addition of certain additives, but in limited concentrations. This bacterium grows and develops when adding $450 \mathrm{ppm}$ of sodium metabisulphite in a vacuum packaged fresh British sausage only if the level of inoculation is $10^{7}$ до $10^{9} \mathrm{CFU} / \mathrm{ml}$. However, an addition of $\mathrm{NaNO}_{2}$ at a concentration of $100 \mathrm{ppm}$ and temperature of $10^{\circ} \mathrm{C}$ prolongs the stage of development of B-2 for 1 day [2].

Besides antimicrobial effects that characterize the B-2, its application in dry and semidry products results in improving their sensory characteristics. There is still no accurate evidence of the inhibitory effect of B-2 on Listeria monocytogenes and other microorganisms, but based on literary data, it is 
considered that the mechanism of "competitive elimination" based on the critical balance of growth development and prevalence of positive microorganisms versus contaminating microorganisms, under specific conditions. is essential factor for the positive effect of this bioprorective culture. The balance may be disturbed during various microorganisms parameters change.

There are several ways to apply the bioprotective cultures in dry and semidry meat products. It is highly recommended B-2 SafePro (Lactobacillus sakei) to be applied by spraying or with automatic pipette after the heat treatment of the meat, or to apply directly to the brine before the appropriate heat treatment. All the accessories used should be sterile from the very beginning of the application procedure under proper hygienic conditions. A suspension of bioprotective cultures is obtained by dissolving it in $1 / 21$ unchlorinated water. A package of $50 \mathrm{~g}$ of the corresponding culture is sufficient for $200 \mathrm{~kg}$ product. Thereby $0,25 \mathrm{ml}$ of the solution is applied to $100 \mathrm{~g}$ of meat product. Once the quantities recommended are applied, $10^{7} \mathrm{CFU} / \mathrm{g}$. approximately is added to the meat.

Meat industries from developed European countries have been already successfully substituted the chemical additives by bioprotective cultures and spices in context of healthier food production. However, the use of bioprotective cultures in meat products have been not implemented by the meat industries in our country. Therefore, it has been a real challenge for us to apply a bioprotective culture B-2 SafePro on burgers, a minced meat grilling product which is very popular in the countries of Central and Eastern Balkan, particularly in Serbia, Bosnia and Herzegovina, Montenegro and Macedonia. A Serbian popular grilled product is well known as "Leskovački" burger, which is usually composed of spicy minced pork or beef. Serbian burgers are their protected brand. The type of a burger depends on the region or a country where it is prepared. Traditionally in Serbia the burger is made from beef, pork or mutton, but most often, by their mixture. In Bosnia and Herzegovina the burger is made exclusively from beef because of the prevalence of Muslim ethnicity in this country. During the ${ }^{-60 \mathrm{es}}, 70 \mathrm{es}, 80 \mathrm{es}$ and $90 \mathrm{es}$ of the last century, the burger represented the main kind of a fast food in Balkan, but even nowadays it is very popular in this region.

The investigation was focused on determining the impact of bioprotective culture B-2 SafePro (Lactobacillus sakei) on certain parameters of burgers, under industrial conditions such as: $\mathrm{pH}$ value; sensory characteristics of the final product; the degree of lipid oxidation (Thibarbituric Acid Reactive Substances - TBARS); the total bacteria count; and the grilling weight loss (shrinkage).

\section{MATERIAL AND METHODS}

Burgers, produced by standard technology procedure in the meat industry "Promes" in Skopje were the subject of investigation. Raw materials composition is given in Table 1 .

Table 1

Raw materials composition of burgers

\begin{tabular}{ll}
\hline \hline Components & Content of raw material (\%) \\
\hline Beef & 65 (70 fresh \& 30 frozen) \\
Chicken gut & 12 \\
Textured soya & 10 \\
Onions & 8 \\
Soya flour & 4 \\
Soya isolate & 1 \\
Sodium chloride & 1.7 \\
Polyphosphates & 0.3 \\
Spices & 0.45 \\
\hline \hline
\end{tabular}

After proper treatment, a homogenous mixture of burgers was obtained and four groups of burgers were made as follows: (R) burgers - without additives, as referent ones; $(\mathrm{R} / \mathrm{B} / \mathrm{A})$ burgers with additives ${ }^{\circ}\left(\right.$ Bombal $^{\mathrm{TM}}$-commercial mixture of: E262 - sodium acetate, E331 - sodium citrate, E315 - iso ascorbic acid, E316 - sodium erythrobate) and antioxidants (E300 - ascorbic acid, E316 - sodium erythrorbate, E330 - citric acid); $(\mathbf{R} / \mathbf{L})$ burgers - with bioprotective culture, B-2 SafePro (Lactobacillus sakei); and $\mathbf{R} / \mathbf{L} / \mathbf{B} / \mathbf{A}$ products - with bioprotective culture, additives ${ }^{\circ}$ and antioxidants.

B-2 SafePro bioprotective culture containing frozen dry form of Lactobacillus sakei and stored at a temperature of $-17^{\circ} \mathrm{C}$ was used when its durability was 18 months. However, if the culture is kept at $+5^{\circ} \mathrm{C}$ its durability is 6 weeks. The culture was packed in aluminum-foil in an amount of $25 \mathrm{~g}$. It was the product of Christian - Hansen company from Denmark. $25 \mathrm{~g}$ bioprotective culture was dissolved in 0.51 of chlorine free water, out of which $25 \mathrm{ml}$ were applied to $10 \mathrm{~kg}$ of raw burger meat. In this study the following methods were applied: 
pH measurement. Measurement of $\mathrm{pH}$ of the burger mixture was performed by digital $\mathrm{pH}$ meter (pH 540 GLP "WTW" - Germany). The electrode and the temperature probe were directly inserted into 6 aliquots of each group of raw, thermally not processed burger mixture. The mean value was calculated out of six measurements. Measurements were conducted at third and seventh day after their production.

Grilling weight loss. Grilling weight loss of the burgers was determined into 6 aliquots from each group, 3 and 7 days after their production by measuring the burger's weight before and after grilling. The difference was expressed in percentage relative to the weight of the product before grilling.

Determining the degree of lipid oxidation (TBARS test). The degree of lipid oxidation in burgers was determined by TBARS test (Thibarbituric Acid Reactive Substances) according to the method of Tarladgis [30], modified by Shahidi [28, 29]. The determination was performed 7 days after their production (the products were stored at temperature of 0 to $4^{\circ} \mathrm{C}$ ) as well as after 90 days (the products were kept at temperature of $\left.-18^{\circ} \mathrm{C}\right)$. TBARS number was determined in burgers (stored overnight in a refrigerator at a temperature of 0 to $4^{\circ} \mathrm{C}$ ). Before determining the number, burgers were grilled, and after cooling at room temperature were stored overnight in a refrigerator at a temperature of $0-4^{\circ} \mathrm{C}$. TBARS test was performed according as follows: In $500 \mathrm{ml}$ distillation flask, $10 \mathrm{~g}$ of homogenized sample was measured and $97.5 \mathrm{ml}$ of distilled water, $2.5 \mathrm{ml} 4 \mathrm{~N} \mathrm{HCl}$, several glass beads and small rod coated with teflon were added. The flask was placed on a magnetic stirrer and the content was mixed for 2 minutes at $1200 \mathrm{rpm}$. Then the content was distilled under the hot water vapor and the distillate was collected in a smaller flask of $50 \mathrm{ml}$. The distillation took about 10 minutes. In a flask of $25 \mathrm{ml}, 5 \mathrm{ml}$ of $0.02 \mathrm{M}$ aqueous solution of thibarbituric acid (TBA) was added to $5 \mathrm{ml}$ of the distillate. $5 \mathrm{ml}$ of distilled water and $5 \mathrm{ml}$ of $0.02 \mathrm{M}$ solution of TBA was used as a blind probe. The flasks were closed by stopper and heated in a boiling water bath for 35 minutes. After water cooling a coloring absorbent was measured, at a wavelength of $532 \mathrm{~nm}$, by spectrophotometer JENWAY 6305. To turn absorbent units into TBARS numbers, defined as a concentration of malonaldehyde in $\mathrm{mg} / \mathrm{kg}$, absorbance units were multiplied by factor of 8.1 [28].

Examination of sensory characteristics. Sensory characteristics such as appearance, color, smell, taste, texture and consistency were investigated, 3 and 7 days after production. Sensory characteristics of the final products (burgers) were estimated by a scoring method [26], carried out by a 5 members taste panelists. The sensory score encompassed 5 features: external appearance, cross section appearance, consistency, smell and taste. Coefficient of importance was defined for each of the following characteristics: external appearance 1 , cross section appearance -4 , consistency -3 color -3 , smell -4 , and taste -5 , a sum of those being 20. Each characteristic got a mark from 1 to 5 (1 - bad, 2 - mild, 3 - good, 4 - very good, 5 excellent). The assessment for each characteristic was multiplied with the coefficient of importance, and the value obtained was noted in a table. Entered values were collected and divided by the sum of the coefficient (20). The value obtained represented an average value or a general assessment of the burger quality. In addition a percentage of maximal quality was calculated, which was a ratio of the weighted average value (WAV) compared to the maximum score (5), i.e. the formula being $\mathrm{WAV} / 5$ X 100.

Investigation of the total number of bacteria in burgers. Microbiological investigations of the referent group of burgers (without bioprotecttive culture) and investigated groups (treated with bioprotective culture) were performed in the Veterinarian Institute in Skopje. Samples were taken 1 and 7 days after the production of burgers for investigation. During the experiment for the microbiological analysis the following standard analytical methods were used: Campylobacter (ISO 10272-2), Yersinia enterocolitica (ISO 10273), Salmonella spp. (ISO 6579), Listeria monocytogenes (ISO 11290-1), E.coli O157 : H7 (ISO 16654), Enterobacteriaceae (ISO 21528-2) and ISO 4833.

\section{RESULTS AND DISCUSSION}

The results of $\mathrm{pH}$ measurements 3 and 7 days after production are presented in Table 2 .

The lowest $\mathrm{pH}$ (6.105) was found in $\mathrm{R} / \mathrm{L} / \mathrm{B}$ + A group of burgers, 3 days after their production, in which a bioprotective culture B-2 SafePro, additives $^{\circ}$ (Bombal $^{T M}$-commercial mixture of: E262 sodium acetate, E331 - sodium citrate, E315 - iso ascorbic acid, E316 - sodium erythrobate) and antioxidants (E 300 - ascorbic acid, E316 - sodium erythorbate, E330 - citric acid) were added. However, the $\mathrm{pH}$ difference among the burger 
groups was small. After 7 days of production, the lowest $\mathrm{pH}$ (5.792) was found in $\mathrm{R} / \mathrm{L}$ burgers where a bioprotective culture B-2 SafePro was added. It is compatible with the findings of Jelle [14] who discovered that in products with B-2 SafePro ${ }^{\mathrm{TM}}$, carbohydrates were converted into lactic acid, which resulted in obvious reduction of $\mathrm{pH}$. Verplaetse [33] and Molly [21] have proven that acidification of meat products, which arises due to proliferation of the bacteria, have multiple positive effects including reduction of $\mathrm{pH}$ and providing hygienic stability of the meat products.

Table 2

pH value at the third and seventh day after production

\begin{tabular}{ccccc}
\hline \hline \multirow{2}{*}{$\begin{array}{c}\text { Days after } \\
\text { production }\end{array}$} & \multicolumn{5}{c}{ Groups of products } \\
& $\mathrm{R}$ & $\mathrm{R} / \mathrm{B}+\mathrm{A}$ & $\mathrm{R} / \mathrm{L}$ & $\mathrm{R} / \mathrm{L} / \mathrm{B}+\mathrm{A}$ \\
\hline 3 & 6.125 & 6.145 & 6.127 & $\mathbf{6 . 1 0 5}$ \\
7 & 5.966 & 5.972 & $\mathbf{5 . 7 9 2}$ & 5.976 \\
\hline \hline
\end{tabular}

The highest $\mathrm{pH}$ (5.976) had $\mathrm{R} / \mathrm{L} / \mathrm{B}+\mathrm{A}$ burgers which contained B-2 SafePro, additives ${ }^{\circ}$ and antioxidants. Lower $\mathrm{pH}$ prolongs the shelf life of this kind of products. Therefore, our results suggest that products with a bioprotective culture should have longer shelf life compared to the other groups after $7^{\text {th }}$ day of production. An additional investigation should be conducted to confirm these findings.
The results from estimated values for weight loss after grilling the burgers are shown in the Table 3.

Table 3

A weight loss (shrinkage) during grilling, 3 and 7 days after production (\%)

\begin{tabular}{ccccc}
\hline \hline $\begin{array}{c}\text { Days after } \\
\text { production }\end{array}$ & \multicolumn{4}{c}{ Groups of products } \\
\hline 3 & $\mathrm{R}$ & $\mathrm{R} / \mathrm{B}+\mathrm{A}$ & $\mathrm{R} / \mathrm{L}$ & $\mathrm{R} / \mathrm{L} / \mathrm{B}+\mathrm{A}$ \\
\hline 7 & 11.283 & 9.920 & 8.4225 & 11.280 \\
\hline \hline
\end{tabular}

The lowest weight loss $(8.4225 \%)$ was noted in $\mathrm{R} / \mathrm{L}$ burgers with a bioprotective culture $\mathrm{B}-2$ SafePro, the third day after the production. A higher weight loss compared to $\mathrm{R} / \mathrm{L}$ group was found in both groups of $\mathrm{R}$ and $\mathrm{R} / \mathrm{L} / \mathrm{B}+\mathrm{A}$ burgers $(11.283 \%$; $11.280 \%$ respectively). The highest shrinkage $(15.755 \%)$ was evident in $\mathrm{R} / \mathrm{L}$ burger group where a bioprotective culture was added compared to percentage values of the rest of the three other groups $\mathrm{R}, \mathrm{R} / \mathrm{B}+\mathrm{A}$ and $\mathrm{R} / \mathrm{L} / \mathrm{B}+\mathrm{A}$ investigated $(15.755 \%$ v. $14.225 \%, 12.238 \%, 12.750 \%$, respectively), 7 days after the production. It should be noted that in $\mathrm{R} / \mathrm{L}$ group we have found the lowest $\mathrm{pH}$ which is compatible with other scientific findings that a decrease of $\mathrm{pH}$ value is followed by a higher shrinkage after thermal treatment - cooking or grilling $[18,31]$.

The results of sensory analysis of burgers 3 days after production are presented in Table 4.

Table 4

Sensory analysis of burgers, 3 days after production

\begin{tabular}{|c|c|c|c|c|c|c|c|c|c|}
\hline \multirow[t]{3}{*}{ Sensory characteristics } & \multirow[t]{3}{*}{ CI* } & \multicolumn{8}{|c|}{ Groups of products } \\
\hline & & \multicolumn{2}{|c|}{$\mathrm{R}$} & \multicolumn{2}{|c|}{$\mathrm{R} / \mathrm{B}+\mathrm{A}$} & \multicolumn{2}{|c|}{$\mathrm{R} / \mathrm{L}$} & \multicolumn{2}{|c|}{$\mathrm{R} / \mathrm{L} / \mathrm{B}+\mathrm{A}$} \\
\hline & & $M^{* *}$ & $\mathrm{C}^{\mathrm{o}}$ & $M^{* *}$ & $\mathrm{C}^{\mathrm{o}}$ & $M^{* *}$ & $\mathrm{C}^{\mathrm{o}}$ & $M^{* *}$ & $\mathrm{C}^{\mathrm{o}}$ \\
\hline Appearance & 1 & 3 & 1 & 3.9 & 3.9 & 4 & 4 & 3.5 & 3.5 \\
\hline Cross section appearance & 4 & 3.6 & 14.4 & 4.2 & 16.8 & 3.8 & 15.2 & 3.8 & 15.2 \\
\hline Consistency & 3 & 3.3 & 9.9 & 4 & 12 & 3.6 & 10.8 & 3.8 & 11.4 \\
\hline Color & 3 & 3 & 9 & 4 & 12 & 3.6 & 10.8 & 3.7 & 11.1 \\
\hline Smell & 4 & 3.5 & 14 & 3.9 & 15.6 & 4 & 16 & 3.9 & 15.6 \\
\hline Taste & 5 & 3.5 & 17.5 & 4.1 & 20.5 & 3.7 & 18.5 & 3.9 & 19.5 \\
\hline Total quality & 20 & & & & & & & & \\
\hline Average value & & & 3.39 & & 4.04 & & 3.77 & & 3.82 \\
\hline$\%$ Maximal effect & & & 67.8 & & 80.8 & & 75.3 & & 76.3 \\
\hline
\end{tabular}

CI* - Coefficient of importance; $\mathrm{C}^{\mathrm{o}}-$ Correction; $\mathrm{M}^{* *}-$ Mark 
According to the sensory analysis of the burgers, the panelists found the best quality results $(80.8 \%)$ in $\mathrm{R} / \mathrm{B}+\mathrm{A}$ burger group (a burger group with additives and antioxidants added), third day after production. On contrary, the worse quality results $(67.8 \%)$ were estimated in $\mathrm{R}$ burger referent group (without bioprotective culture, additives or antioxidants). The results of sensory analysis of investigated burgers, 7 days after the production is shown on Table 5 bellow.

Table 5

Sensory analysis of burgers, 7 days after their production

\begin{tabular}{|c|c|c|c|c|c|c|c|c|c|}
\hline \multirow{3}{*}{$\begin{array}{l}\text { Sensory } \\
\text { characteristics }\end{array}$} & \multirow[t]{3}{*}{$\mathrm{CI}^{* *}$} & \multicolumn{8}{|c|}{ Groups of products } \\
\hline & & \multicolumn{2}{|c|}{$\mathrm{R}$} & \multicolumn{2}{|c|}{$\mathrm{R} / \mathrm{B}+\mathrm{A}$} & \multicolumn{2}{|c|}{$\mathrm{R} / \mathrm{L}$} & \multicolumn{2}{|c|}{$\mathrm{R} / \mathrm{L} / \mathrm{B}+\mathrm{A}$} \\
\hline & & $\mathrm{M}^{* *}$ & $\mathrm{C}^{\mathrm{o}}$ & $\mathrm{M}^{* *}$ & $\mathrm{C}^{\mathrm{o}}$ & $\mathrm{M}^{* *}$ & $\mathrm{C}^{\mathrm{o}}$ & $\mathrm{M}^{* *}$ & $\mathrm{C}^{\mathrm{o}}$ \\
\hline Appearance & 1 & 2.75 & 2.75 & 3.875 & 3.88 & 4.5 & 4.5 & 3.75 & 3.75 \\
\hline Cross section & 4 & 2.5 & 10 & 3.75 & 15 & 4.5 & 18 & 3.88 & 15.5 \\
\hline Consistensy & 3 & 2.25 & 6.75 & 4 & 12 & 4.38 & 13.13 & 3.75 & 11.50 \\
\hline Color & 3 & 2.63 & 7.88 & 3.63 & 10.88 & 4.5 & 13.5 & 4 & 12 \\
\hline Smell & 4 & 2.375 & 9.5 & 3.625 & 14.5 & 4.375 & 17.5 & 3.75 & 15 \\
\hline Taste & 5 & 2.25 & 11.25 & 3.75 & 18.75 & 4.5 & 22.5 & 4.125 & 20.625 \\
\hline Total quality & 20 & & & & & & & & \\
\hline Average value & & & 2.40 & & 3.75 & & 4.45 & & 3.91 \\
\hline$\%$ maximal effect & & & 48.13 & & 75 & & 89.13 & & 78.38 \\
\hline
\end{tabular}

$\mathrm{CI}^{*}-$ Coefficient of Importance; $\mathrm{C}^{\mathrm{o}}-$ Correction; $\mathrm{M}^{* *}-$ Mark

The tasters estimated the best quality results including all sensory characteristics $(89.13 \%)$ in $\mathrm{R} / \mathrm{L}$ group of burgers where bioprotective culture B-2 SafePro was added, 7 days after the production compared to referent $\mathrm{R}$ group of burgers ( $89.13 \%$ v. $48.13 \%$ ) which is confirmed by other authors as well. In such a meat product, where bioprotective culture was added, it initiated a chain of reactions which induced a desirable improvement of the all sensory characteristics [33]. The bioprotective cul- ture reduced the water binding ability of meat product obtaining the desirable texture $[15,22]$. During the maturation process of cevapi, myoglobin is denatured to miohromogen of nitrogen monoxide. This process increased the color stability because nitrogen monoxide slowly deliberates from chem-group [11]. The results of microbiological investigations the first and seventh day of production are presented in Table 6 .

Table 6

Total bacteria count 1 and 7 days after production

\begin{tabular}{lcccc}
\hline \hline Total bacteria count & $\mathrm{R}$ & $\mathrm{R} \backslash \mathrm{B}+\mathrm{A}$ & $\mathrm{R} \backslash \mathrm{L}$ & $\mathrm{R} \backslash \mathrm{L} \backslash \mathrm{B}+\mathrm{A}$ \\
\hline 1 day after production & 4.700 .0000 & 2.600 .000 & 8.600 .000 & $\mathbf{1 2 . 6 0 0 . 0 0 0}$ \\
7 days after production & $3200 \cdot 10^{5}$ & $2800 \cdot 10^{5}$ & $\mathbf{4 0 0 0} \cdot \mathbf{1 0}^{\mathbf{5}}$ & $>3000 \cdot 10^{5}$ \\
\hline \hline
\end{tabular}

Microbial investigations showed a highest total bacteria count, 7th day after production in $\mathrm{R} / \mathrm{L}$ burgers with bioprotective culture. It was verified that a higher number of bacteria was on the count of multiplied colonies of Lactobacillus sakei. LAB can promote a revitalization of the positive micro- flora and prevent the development of undesirable microflora, so the need for application of physical or chemical preservation have been reduced [6].

According to Jelle [14], the application of B-2 SafePro resulted in inhibition of Listeria monocytogenes, Brochothrix thermosphacta, Leuconostoc 
$s p$. which are the part of putrefying flora. These results were confirmed by Krockel [19] who investigated the alternative of a high quality and microbiological safe products of minced beef meat by using biocultures of L. sakei, L. curvatus and $L$. paracasei when L. sakei had the most intensive growth. Tyoponnen [31] confirmed an intensive growth of $L$. sakei in chicken breasts meat treated with this bioculture, 29 days after the production. The products had typical color and texture compared to non treated products.

In order to determine the antioxidant action of the bioprotective culture B-2 SafePro in burgers, the samples were investigated in two conditions:

1. Samples were kept 7 days after production at a temperature of $0-4^{\circ} \mathrm{C}$.

2. The samples were investigated 90 days after the production at temperature of $-18^{0} \mathrm{C}$, after which period a TBAR test was performed. The results are shown on Table 8 .

\section{Table 8}

\section{The content of malonaldehyde $(\mathrm{mg} / \mathrm{kg})$ in burgers}

\begin{tabular}{lcccc}
\hline \hline $\begin{array}{l}\text { Days after } \\
\text { production }\end{array}$ & $\ldots \ldots \ldots \ldots \ldots \ldots \ldots \ldots \ldots \ldots \ldots \ldots \ldots \ldots \ldots \ldots \ldots \ldots \ldots \ldots \ldots \ldots \ldots \ldots \ldots \ldots \ldots \ldots \ldots \ldots \ldots \ldots \ldots \ldots \ldots \ldots \ldots \ldots \ldots \ldots$ \\
$\begin{array}{l}\text { Temperature } \\
\text { of storage }\end{array}$ & $\mathrm{R}$ & $\mathrm{R} / \mathrm{B}+\mathrm{A}$ & $\mathrm{R} / \mathrm{L}$ & $\mathrm{R} / \mathrm{L} / \mathrm{B}+\mathrm{A}$ \\
\hline $7\left(0-4^{0} \mathrm{C}\right)$ & 0.5751 & 0.324 & 0.3645 & 0.2916 \\
$90\left(-18^{0} \mathrm{C}\right)$ & 0.7047 & 0.9801 & 0.8262 & $\mathbf{0 . 5 6 7}$ \\
\hline \hline
\end{tabular}

The $\mathrm{R} / \mathrm{L} / \mathrm{B}+\mathrm{A}$ burgers have the lowest value for TBARS $(0.567 \mathrm{mg} / \mathrm{kg})$, which suggests that this product has the lowest degree of lipid oxidation. This finding suggests that the best degree of lipid oxidation is achieved with a combination of bioprotective culture, additives and antioxidants. Gerhardt [10], Lamaison [20] and Fasseas [9] detected that an addition of oregon or sage to the minced beef meat stored at $4^{\circ} \mathrm{C}$ have the best antioxidant effect confirmed by TBARS lowest value compared to referent group of product where unacceptable sensory characteristics were found.

\section{CONCLUSION}

1. An addition of bioprotectective culture (B2 Safe Pro - Lactobacillus sakei) to burgers has a positive impact on their $\mathrm{pH}$, sensory characteristics and microbial profile, inducing their prolonged shelf life.
2. A combination of bioprotective culture, additives and antioxidants added to burgers has the best effect on the degree of lipid oxidation in this product.

3. Further investigation should be focused on discovering the best combination of bioculture, additives and antioxidans for these types of products.

\section{REFERENCES}

[1] Abbe T., L. Krockel, C. Hill C.: Bacteriocins: modes of action and potentials in food preservation and control of food poisoning, Int. J. Food Microbiol., 28, 169-185 (1995).

[2] Andersen L.: Bioprotective cultures for fresh sausages. Fleischwirtschaft, 3, 22-24 (1997).

[3] Axelsson L, Ahrné S.: Lactic acid bacteria. In: Applied Microbial Systematics. Priest F., G. Goodfellow, M. Dordrechet (Eds), Kluwer Academic Press, Netherlands, 2000, pp 365-386.

[4] Bibek R., Bunija E.: Osnovna mikrobiologija na hrana, Ars Lamina, Skopje, 2010.

[5] Chaillou S., Champomier Vergès M. C., Cornet M., CrutzLe Coq A. M. et al: The complete genome sequence of the meat-borne lactic acid bacterium Lactobacillus sakei 23K. Nat Biotechnol, 23, 1527-533 (2005).

[6] Chaillou S., Christieans S., Rivollier M., Lucquin I., Champomier-Vergès M. C., Zagorec M.: Quantification and efficiency of Lactobacillus sakei strain mixtures used as protective cultures in ground beef. Meat Sci., 97 (3), 332-8 (2014).

[7] Chiaramonte F., Blugeon S., Chaillou S., Langella P., Zagorec M.: Behavior of the meat borne bacterium Lactobacillus sakei during its transit through the gastrointestinal tracts of axenic and conventional mice. Appl Environ Microbiol, 75, 4498-505 (2009).

[8] Demeyer D. I.: Meat fermentation as an integrated process. New technologies for meat and meat products, 21-36 (1992), The Netherlands..

[9] Fasseas M. K., Mountzouris C. K., Tarantilis P. A., Zervas G.: Antioxidant activity in meat treated with oregano and sage essential oils. Food Chemistry. 106 (3), 1188-1194 (2008).

[10] Gerhardt U.: Plant. Essent. Oils. Fleischwirtschaft. 64: 484-486 (1984).

[11] Hammes W. P., Bantleon A., Min S.: Lactic acid bacteria in meat fermentation. FEMS Microbiol Rev, 87, 165-174 (1990).

[12] Hammes W. P., Hertel C.: New developments in meat starter cultures. Meat Science, 49, 125-138 (1998).

[13] Holzapfel W., Geisen R. and Schillinger U.: Biological preservation of food with reference to protective cultures, bacteriocins and food-grade enzymes. Int $J$ Food Microbiol, 24, 343-362 (1995).

[14] Jelle B.: Biokonserving af charcuterivarer. Chr. Hansen's labaratorium. Danmark. A/S, 1991. 
[15] Kato H., Rhue M. R., Nishimura T.: Role of free amino acids and peptides in food taste. ACS Symposium Series, Washington, 158 (1989).

[16] Katikou P., Ambrosiadis I., Georgantelis D., Koidis P., Georgakis S. A.: Effect of Lactobacillus-protective cultures with bacteriocin-like inhibitory substances' producing ability on microbiological, chemical and sensory changes during storage of refrigerated vacuum-packaged sliced beef. Appl. Microbiology, 99 (6), 1303-13 (2005).

[17] Klaenhammer T., Altermann E., Arigoni F., et al.: Discovering lactic acid bacteria by genomics. Antonie van Leeuwenhoek, Kluwer Academic Publishers. Netherlands, 82, 29-58 (2002).

[18] Kraft A.: Psychotrophic bacteria in foods: Diseases and spoilage. CRC Press, Boca Raton, FL, 121, 1992.

[19] Krockel L., Dederer I., Troeger K.: Starter and Protective Cultures for Meat Products. Fleischwirtschaft, 93-98 (2011).

[20] Lamaison J.: L. Ann. Pharm. Franc. 48: 303-308 (1988).

[21] Molly K., D. Demeyer, G. Johansson, M. Raemaekers, M. Ghistelinck and I. Geemem: The importance of meat enzymes in ripening and flavor generation in dry fermented sausage. First result of a European project. Food Chem. 59, 539-545 (1997).

[22] Nishimura T., Rhue M. R., Oktiani A., and Kato H.: Components contributing to the improvement of meat taste during storage. Agric Biol Chem. 52: 2323-2330 (1988).

[23] Palanisamy I., Thirumalai M., Ramasamy R., Santhiyagu P., Chandrasekaran K., Grasian I., Arunachalam P.: Optimization of bacteriocin production by Lactobacillus sp. MSU3IR against shrimp bacterial pathogens. Aquat Biosyst., 9: 12 (2013).

[24] Papon M. and Talon R.: Factor affecting growth and lipase production by meat lactobacilli strains and Brochotrix thermosphacta. J Appl Bacteriol, 64, 107-115 (1988).

[25] Phumkhachorn P. and Rattanachai K. P.: Lactic acid bacteria: their antimicrobial compounds and their uses in food production. Annals of Biological Research, 1 (4), 218-228 (2010).

[26] Radovanović R., Popović-Raljić J.: Senzorna analiza prehrambenih proizvoda, Poljoprivredni fakultet, Beograd i Tehnološki fakultet, Novi Sad, 2001.

[27] Sinha R., Park Y., Graubard I. B., et al.: Meat and Meatrelated Compounds and Risk of Prostate Cancer in a Large Prospective Cohort Study in the United States. American Journal of Epidemiology, 10-15 (2009).

[28] Shahidi F., Rubin L. J., Diosady L. L.: Alternative meat curing systems. 2. Control of oxidative rancidity. 26th Annual meeting of the Canadian Institute of Food Science and Technology, N 82, 1983.

[29] Shahidi F., Rubin L. J., Wood D. F.: Control of lipid oxidation on cooked ground pork whit antioxidant and dinitrosyl ferrohemochrome. Jurnal of Food Science, 52 (3), 564-567 (1987).

[30] Tarladgis B. G., Watts B. M., Younathan M. T., Dugan J. L.: Distillation method for the quantitative determination of malonaldehyde in pancid foods. Journal of the American Oil Chemists Society, 37-44 (1960).

[31] Tyopponen S., Petajja E. and Mattila-Sanholm T.: Bioprotective cultures for dry sausages. International Journal of Food Microbiology, 83, 233-244 (2003).

[32] Vermeiren L., Devlieghere F., Debevere J.: Evaluation of meat born lactic acid bacteria as protective cultures for biopreservation of cooked meat products. Int $J$ Food Microbiol, 96, 149-164 (2004).

[33] Verplaetse, A.: Influence of raw meat properties and processing on aroma quality of raw fermented meat products. Proc. $40^{\text {th }}$ Int. Congr. Meat. Sci. and technol. The Hague, The Netherlands, 45, 1994.

[34] Vogel R. F., Lohmann M., Nguyen M., Weller A. N., Hammes W. P.: Molecular characterization of Lactobacillus curvatus and Lact. sake isolated from sauerkraut and their application in sausage fermentations. $J$ Appl Bacteriol, 74, 295-300 (1993).

[35] Wilson C. L.: Микробна конӣаминащија на хранаӣа, Арс Ламина, Скопје, 2011.

[36] www.nofima.no/filearchive/melkesyrebakterier.runge_5.pd 